\title{
THE CONTRIBUTION OF GOVERNMENT AND NON GOVERNMENTAL ORGANIZATION SUPPORT FOR EDUCATION IN BENIN CITY, NIGERIA.
}

\author{
Ehiaghe IJ2, Ehiaghe FA*1, Aladenika S3,Osakue E3 Osakue O4, Iyen IR2
}

1. Department of Hematology, College of Health Sciences, Igbinedion University, Okada. Nigeria.

2. Lahor Research and medical centre, 121, Old Benin -Agbor Road, Benin City, Nigeria.

3. Department of Pathology, Igbinedion University Teaching Hospital, Okada.

4. Department of Medical Laboratory science, University of Benin, Nigeria.

\section{ABSTRACT}

This study was aimed at identifying and examining the various supports for secondary school education by the government and NGOs in Benin City. Out of the fifteen (15) experiencing government refurbishment in Edo State, 4 are in Benin metropolis and all 4 were sampled. 40 questionnaires were administered (10 for each school). The results of the investigation carried out using percentage distribution and Chi Square Testing. The contributions of both Government and NGO were responsible for the positive improvement in the educational system in Benin City and in Nigeria since independence, although NGO support have not really been significant. The Planning, Research and Statistic Department of Post Primary Education Board and that of the Ministry of Education in the state should carry out the actual counting of schools and their staffs as well as students in the school so that they can be suitably used for planning.

\section{Keywords:}

Universal Basic Education; secondary school education; Non-governmental organization; Benin City; Teachers.

\section{Council for Innovative Research}

Peer Review Research Publishing System

Journal of Social Science Research

Vol.3, No.2

editor@jssronline.com

www.cirworld.com, www.jssronline.com 


\section{Introduction}

In 2000 , Nigeria's literacy rate was $52 \%$ (1). In 1998, only $40 \%$ of all heads of households in Nigeria had any education at all, $21 \%$ had only primary education, $14 \%$ had up to secondary education, while only $5 \%$ had post-secondary education, (2). Data from the Federal Ministry of Education, education Statistics (1996) showed that only 14.1 million out of 21 million school age children are enrolled in primary school. UBE was born from those startling statistics, to promote education among all citizens. Efforts by government to promote education and literacy in Nigeria have failed because there was no provision for school libraries in the implementation of those programmes. The successful implementation of the UBE has serious implication for school libraries. It indicates an expanded vision for school libraries to include not only libraries in primary and secondary school but also libraries for early childhood education, (3).

The World Bank is the single largest external financer of education in the world, with education at the heart of the World Bank's mission to reduce global poverty, the World Bank also adopts educational standards established by other international intergovernmental organization such as their implementation of the Organization for Economic Cooperation and Development (OECD), which establishes specific international targets for primary, secondary and gender parity on the basic education with the Education for All initiative (4).Nigeria as a country of multi-ethnic cultural diversities with about 140 million in population. Education is the best legacy a country can give to her citizens (5). Education improves the development of any society and the youths who occupy significant positions in that country should be properly educated in order to improve the society, (6). The purpose of the study is to identify the various supports for secondary school education by the government and NGOs in Benin City.

\section{Population of study}

Out of the fifteen (15) experiencing government refurbishment in Edo State, 4 are in Benin metropolis and all 4 were sampled.

\section{Data Presentation}

\section{The schools sampled are}

1.Edo Boys High School, Ugbowo, Benin City (Egor Local Government Area). 2.Idia College, lyaro, Benin City, (Oredo Local Government Area).

3.Niger College, Sokponba Road, Benin City, (Ikpoba Okha Local Government Area). 4.St. Maria Goretti, Sokponba Road, Benin City, (Ikpoba-Okha Local Government Area)

\section{Questionnaire Analysis}

40 questionnaires were administered (10 for each school). The following tables represent the result of the investigation carried out using percentage distribution and Chi Square Testing:

Table 4.1 Respondents responses

\begin{tabular}{|l|l|l|l|l|l|}
\hline S/N & \multicolumn{1}{|c|}{ Item } & Question No. & Adequate & \multicolumn{1}{|c|}{ Inadequate } & \multicolumn{1}{|c|}{ Absent } \\
\hline 1 & Teachers welfare & 8 & 32 & 8 & 0 \\
\hline 2 & Library facility & 17 & 14 & 16 & 10 \\
\hline 3 & Classroom & 17 & 22 & 16 & 0 \\
\hline 4 & Sciences laboratory & 17 & 19 & 21 & 0 \\
\hline 5 & Teaching Aids & 17 & 14 & 26 & 0 \\
\hline 6 & Staff room & 17 & 36 & 4 & 0 \\
\hline 7 & Computer facility & 17 & 12 & 19 & 9 \\
\hline 8 & Audio-visual & 22 & 11 & 14 & 15 \\
\hline 9 & Students performance & 26 & 24 & 12 & 4 \\
\hline
\end{tabular}

\begin{tabular}{|l|l|l|l|l|c|}
\hline S/N & \multicolumn{1}{|c|}{ Item } & Question No. & Yes (Present) & No (Present) & Blank \\
\hline 1 & NGO support & 9 & 11 & 29 & 0 \\
\hline 2 & Favorable Government & 14 & 27 & 8 & 5 \\
\hline 3 & Educational Policy & 16 & 27 & 8 & 5 \\
\hline 4 & Improved security and learning environment & 24 & 36 & 4 & 0 \\
\hline
\end{tabular}


Table 4.2 Percentage Analysis of Respondents' Responses

\begin{tabular}{|l|l|l|l|l|l|}
\hline S/N Item & \multicolumn{1}{|c|}{ Adequate } & \multicolumn{1}{|c|}{ Inadequate } & Absent \\
\hline 1 & Teachers welfare & 8 & 20 & 0 \\
\hline 2 & Library facility & 17 & 80 & 40.0 \\
\hline 3 & Classroom & 17 & 35.0 & 45.0 \\
\hline 4 & Sciences laboratory & 17 & 55.0 & 52.5 \\
\hline 5 & Teaching Aids & 17 & 47.5 & 6 \\
\hline 6 & Staff room & 17 & 35.0 & 0 \\
\hline 7 & Computer facility & 17 & 90.0 & 10.0 \\
\hline 8 & Audio-visual & 17 & 30.0 & 47.5 \\
\hline 9 & Students performance & 25 & 27.5 & 0 \\
\hline
\end{tabular}

\begin{tabular}{|c|l|l|l|l|l|}
\hline S/N & \multicolumn{1}{|c|}{ Item } & Question No. & Yes (Present) & \multicolumn{1}{|c|}{ No (Present) } & \multicolumn{1}{c|}{ Blank } \\
\hline 10 & NGO support & 9 & 30 & $29 / 70$ & - \\
\hline 11 & Favorable Government & 14 & 67.5 & 20 & 12.5 \\
\hline 12 & Educational Policy & 16 & 67.5 & 20 & 12.5 \\
\hline 13 & Improved security and learning environment & 24 & 90 & 10 & - \\
\hline 14 & Teachers Welfare & 8 & 80 & 20 & - \\
\hline
\end{tabular}

Table 4.3 Teachers Welfare Chi Square Testing

\begin{tabular}{|l|l|l|l|l|l|}
\hline \multicolumn{1}{|c|}{ Responses } & \multicolumn{1}{|c|}{ Observed $(\mathrm{E})$} & Oxpected $(\mathrm{E})$ & $\mathrm{O}-\mathrm{E}$ & $\mathrm{O}-\mathrm{E}) 2$ & $\mathrm{O}-\mathrm{E}) 2 / \mathrm{E}$ \\
\hline Yes & 32 & 20 & 12 & 144 & 6.2 \\
\hline No & 8 & 20 & -12 & 144 & 6.2 \\
\hline Total & 40 & 40 & & & 12.4 \\
\hline
\end{tabular}

$80 \%$ of respondents ticked or acknowledged government support for teachers' welfare (increase salary/promotion), while only $20 \%$ indicated that there is no government support for improved teachers' welfare. Table 4.3 above showed that the calculated Chi Square value (Ccal) is 12.4 and the Critical value (Ccrit) or Table value (6.7) for one degree of freedom (df) at 0.05 level of significance is 3.84 . Hence the Ccal is greater than the Ccrit which confirm that there is a significant government support for secondary school education by the increased salary and promotion for teachers.

Table 4.4 Library Facilities Chi Square Testing

\begin{tabular}{|l|l|l|l|l|l|}
\hline \multicolumn{1}{|c|}{ Responses } & \multicolumn{1}{c|}{ Observed $(\mathrm{E})$} & \multicolumn{1}{c|}{ Expected $(\mathrm{E})$} & \multicolumn{1}{c|}{$(\mathrm{O}-\mathrm{E}) 2$} & $\mathrm{O}-\mathrm{E}) 2 / \mathrm{E}$ \\
\hline Adequate & 14 & 13.333 & 0.67 & 0.45 & 0.04 \\
\hline Inadequate & 16 & 13.333 & 2.67 & 7.13 & 0.54 \\
\hline Absent & 10 & 13.333 & -3.33 & 11.09 & 0.83 \\
\hline Total & 40 & 40 & & & 1.41 \\
\hline
\end{tabular}

$35 \%$ of respondents indicated that library facilities were adequate, $40 \%$ indicated that it was inadequate and $25 \%$ indicated that library facilities was absent. The Ccal (1.41) is less than Crit (7.82), which confirm that library facilities were inadequate where present at all.

Table 4.5 Classroom Chi Square Testing

\begin{tabular}{|l|l|l|l|l|l|}
\hline \multicolumn{1}{|c|}{ Responses } & \multicolumn{1}{|c|}{ Observed (E) } & \multicolumn{1}{c|}{ Expected (E) } & O-E & (O-E)2 & O-E)2/E \\
\hline Adequate & 22 & 13.334 & 8.67 & 75.11 & 5.63 \\
\hline Inadequate & 18 & 13.333 & 4.67 & 21.78 & 1.63 \\
\hline Absent & 0 & 13.333 & -3.33 & 177.78 & 13.333 \\
\hline Total & 40 & 40 & & & 20.503 \\
\hline
\end{tabular}

$55 \%$ of the respondent indicated that the classroom where adequate, $45 \%$.Chi square testing of $20.50 \mathrm{Ccal}$ and $7.815 \mathrm{Crit}$ showed that government supported secondary schools adequately by the provision of classrooms for secondary school in Benin City. 
Table 4.6 Science Laboratory Chi Square Testing

\begin{tabular}{|l|l|l|l|l|l|}
\hline \multicolumn{1}{|c|}{ Responses } & \multicolumn{1}{|c|}{ Observed (E) } & \multicolumn{1}{c|}{ Expected (E) } & \multicolumn{1}{c|}{ O-E } & \multicolumn{1}{c|}{ O-E)2 $2 / \mathrm{E}$} \\
\hline Adequate & 19 & 13.334 & 5.67 & 32.15 & 2.41 \\
\hline Inadequate & 21 & 13.333 & 1.58 & 2.48 & 0.19 \\
\hline Absent & 0 & 13.333 & -3.33 & -177.78 & 15.93 \\
\hline Total & 40 & 40 & & & 15.93 \\
\hline
\end{tabular}

$47.5 \%$ indicated that science laboratory was adequate, while $52.5 \%$ indicated inadequate. And the chi square testing revealed that the Ccal (15.93) is greater than Crit (7.815) showing that there is a significant government support for secondary school education by providing science laboratory.

Table 4.7 Teaching Aids Chi Square Testing

\begin{tabular}{|l|l|l|l|l|l|}
\hline \multicolumn{1}{|c|}{ Responses } & \multicolumn{1}{|c|}{ Observed (E) } & \multicolumn{1}{|c|}{ Expected (E) } & \multicolumn{1}{c|}{ (O-E)2 } & O-E)2/E \\
\hline Adequate & 14 & 13.334 & 0.67 & 0.45 & 0.03 \\
\hline Inadequate & 26 & 13.333 & 1.58 & 160.53 & 12.04 \\
\hline Absent & 0 & 13.333 & -3.33 & -177.78 & 13.33 \\
\hline Total & 40 & 40 & & & 25.40 \\
\hline
\end{tabular}

The percentage distribution showed that only $35 \%$ of the respondents indicated that the teaching aids were adequate while $65 \%$ indicated that it is inadequate and the above chi square Testing revealed that the Ccal $(25.40)$ is greater than Crit (7.18) showing that there is a significant government support for secondary school education by providing Teaching aids.

Table 4.8 Staff Room Chi Square Testing

\begin{tabular}{|c|c|c|c|c|c|}
\hline Responses & Observed (E) & Expected (E) & O-E & $(\mathrm{O}-\mathrm{E}) 2$ & O-E)2/E \\
\hline Adequate & 36 & 13.334 & 16.67 & 277.56 & 20.84 \\
\hline Inadequate & & 13.333 & -9.33 & 89.05 & 1.53 \\
\hline Absent & & 13.333 & -3.33 & 177.78 & 13.33 \\
\hline Total & 40 & 40 & & & 40.7 \\
\hline & & & & & \\
\hline & & & & & \\
\hline
\end{tabular}

$10 \%$ respondents indicated that the staff room was inadequate while $90 \%$ adequate. The above chi square confirm that there is a significant government support for secondary school education by providing adequate staffroom since the Ccal (40.7) is greater than the Crit $(7.815)$ value.

Table 4.9 Computer Facility Chi Square

\begin{tabular}{|l|l|l|l|l|l|}
\hline \multicolumn{1}{|c|}{ Responses } & \multicolumn{1}{c|}{ Observed (E) } & \multicolumn{1}{c|}{ Expected (E) } & \multicolumn{1}{c|}{ O-E } & \multicolumn{1}{c|}{$(\mathrm{O}-\mathrm{E}) 2$} & O-E)2/E \\
\hline Adequate & 12 & 13.334 & -1.33 & 1.77 & 0.13 \\
\hline Inadequate & 19 & 13.333 & 5.67 & 32.15 & 2.41 \\
\hline Absent & 9 & 13.333 & -4.33 & 18.75 & 1.41 \\
\hline Total & 40 & 40 & & & 3.95 \\
\hline
\end{tabular}


$30 \%$ of the respondent indicated adequate, $47.5 \%$ Inadequate and $22.5 \%$ indicated that it is absent and the chi-square testing revealed that the $\mathrm{Ccal}(3.95)$ is less than the Crit (7.815) showing that there is no significant government support for secondary school education by providing computer laboratory.

Table 4.10 Audio - Visual Facilities Chi Square Testing

\begin{tabular}{|l|l|l|l|l|l|}
\hline \multicolumn{1}{|c|}{ Responses } & \multicolumn{1}{|c|}{ Observed (E) } & \multicolumn{1}{c|}{ Expected (E) } & O-E & & O-E)2/E \\
\hline Adequate & 11 & 13.334 & 2.33 & 5.43 & 0.41 \\
\hline Inadequate & 15 & 13.333 & 1.67 & 2.79 & 0.21 \\
\hline Absent & 14 & 13.333 & 0.67 & 0.44 & 0.003 \\
\hline Total & 40 & 40 & & & 0.65 \\
\hline
\end{tabular}

From Table 4.4, only $27.5 \%$ indicated that audio-visual facilities is adequate (present), $35 \%$ indicated that it is inadequate while $37.5 \%$ ticked absent and the chi square testing showed that there is no significant government support for secondary school education by providing audio-visual facilities given the Ccal $(0.65)$ is less than the Crit (7.815) at 0.05 and still less than Crit $(1.323$ at 0.75 that is nearly all the schools $(75 \%)$ lack audio-visual facilities.

Table 4.11 Student Performance

\begin{tabular}{|l|l|l|l|l|l|}
\hline \multicolumn{1}{|c|}{ Responses } & \multicolumn{1}{|c|}{ Observed $(\mathrm{E})$} & \multicolumn{1}{c|}{ Expected $(\mathrm{E})$} & \multicolumn{1}{c|}{$\mathrm{O}-\mathrm{E}$} & \multicolumn{1}{c|}{$\mathrm{O}-\mathrm{E}) 2$} & $\mathrm{O}-\mathrm{E}) 2 / \mathrm{E}$ \\
\hline Very Well & 24 & 13.334 & 10.67 & 113.85 & 8.54 \\
\hline Average & 12 & 13.333 & -1.33 & 1.77 & 0.13 \\
\hline No Effect & 4 & 13.333 & -9.33 & 87.05 & 6.53 \\
\hline Total & 40 & 40 & & & 15.20 \\
\hline
\end{tabular}

The percentage distribution revealed that $69 \%$ of the respondents ticked Very Well, $30 \%$ ticked Average and only $1 \%$ ticked No Effect showing that government support for secondary school education resulted in visible or appreciable students' performance in school activities. The chi-square testing confirms that government support for secondary school have resulted in a significant increase in student's performance since the Ccal (15.2) is greater than the Crit (7.815).

Table 4.12 Ngo Support Chi Square Testing

\begin{tabular}{|l|l|l|l|l|l|}
\hline \multicolumn{1}{|c|}{ Responses } & \multicolumn{1}{|c|}{ Observed (E) } & Expected (E) & O-E & (O-E)2 & O-E)2/E \\
\hline Yes & 12 & 20 & -8 & 64 & 1.6 \\
\hline No & 28 & 20 & 8 & 64 & 1.6 \\
\hline Total & 40 & 40 & & & 3.2 \\
\hline
\end{tabular}

$30 \%$ of the respondents ticked yes, while $70 \%$ ticked NO indicating that there is no significant NGO support for secondary school education in Benin City. And the chi-square testing above revealed that the Ccal (3.2) is less than the Crit (7.815) which confirms that there is no significant NGO for secondary school education in Benin City.

Table 4.14 Favorable Educational Policy

\begin{tabular}{|l|l|l|l|l|l|}
\hline \multicolumn{1}{|c|}{ Responses } & \multicolumn{1}{c|}{ Observed $(\mathrm{E})$} & \multicolumn{1}{c|}{ Oxpected $(\mathrm{E})$} & \multicolumn{1}{c|}{$(\mathrm{O}-\mathrm{E}) 2$} & $\mathrm{O}-\mathrm{E}) 2 / \mathrm{E}$ \\
\hline Yes & 27 & 17.5 & 9.5 & 90.25 & 5.16 \\
\hline No & 8 & 17.5 & -9.5 & 90.25 & 5.16 \\
\hline Total & 35 & 35 & & & 10.32 \\
\hline
\end{tabular}

$67.5 \%$ ticked yes, while $20 \%$ ticked no and $12.5 \%$ ticked absent. Indicating that Government Educational Policies favor Secondary Schools in Benin City and the Chi Square testing confirms that government educational policies have been to the benefit of secondary school education particularly in Benin City since the Ccal (10.32) is greater than the Crit (7.815). The above analyses showed that secondary school education have been improved by government particularly the present government. However, the analysis also showed that some areas of education still need adequate support. Education funds are reported to be distributed among the primary, secondary and tertiary education levels in the proportion of $30 \%, 30 \%$ and $40 \%$ respectively. The public funding includes direct government expenditure as well as indirect expenditure in the form of subsidies to households such as tax reduction, scholarships, loans and grants, the main sources of fund that the Nigeria government has are federal taxes and duties on petroleum. At present private sources 
(NGOs) account for about $20 \%$ of total national donors. Nigeria has not met the $26 \%$ of total budgetary allocation to education recommended by UNESCO, the total federal allocation to education had been decline from $11.13 \%$ in 1990 s to $7.0 \%$ in $2001(7,8,9,10)$.

The analyses of data revealed that teachers welfare and thus efficiency have greatly been increased (Table $4.1,4.13)$ students performance too have also significantly improved, which means that teachers efficiency is going to continuously experience an upsurge and better trained and development students will be graduated into the society or labour market. The test results also revealed that the increased Government support for education have improved the security and conducive learning environment.

\section{Conclusion}

The contributions of both government and non governmental organization were responsible for the positive improvement in the educational system in Benin City.

\section{REFERENCES}

1. Balami, O. (2002) Finance of Education in Nigeria paper presented the forum of cost and finance of Education in Nigeria, Abuja.Pp12-15.

2. United Nation Development Programme (1998). Nigeria Human Development Report Lagos. UNDP.Pp 56-60.

3. Dike, V.W. (2003). Library Resources in Education. Enugu: ABIC Pp.21-25.

4. World Bank Education (1999) Education Sector Strategy (Washington, DC; the International Bank for Reconstruction and Development. Pp 7-9.

5. World Bank Education (1999) Education Sector Strategy (Washington, DC; the International Bank for Reconstruction and Development. Pp 7-9.

6. Obani, T.C. (1996). The Vision and Mission of Special Education in Nigeria. A lead paper presented at National Commission for Colleges of Education (NCCE) at the National Conference, NTI, Kaduna.Pp 34-36.

7. Federal Ministry of Education (2000). Implementation Guidelines for the Universal Basic Education (UBE) Programme; Abuja; Federal Ministry of Education. Pp 3-4.

8. Balami, O. (2002) Finance of Education in Nigeria paper presented at the forum of cost and finance of Education in Nigeria, Abuja.Pp12-15.

9. Eya, P. (2001). The extent of primary school teachers' awareness and involvement in Universal Basic Education in Enugu Urban Areas. Pp.22-25.

10. Spring, J.H. (2004) How Educational Ideologies are shaping Global Society. Intergovernmental organizations, NGO's and the Decline of the Nation State Mahwah, NJ; Lawrence Erlbaum Associates Pp.33-35. 